\title{
Leadership and the land-grants: the case of Milton S. Eisenhower
}

\author{
Steven P. Dandaneau \\ Vice Provost for Undergraduate Studies and Associate Professor of Sociology, Kansas State University, \\ Manhattan, KS, USA
}

How will land-grant universities fulfill their democratic mission in an era of declining public support? A case study of Milton S. Eisenhower's presidency of Kansas State College (1943-1950) explores the entrenched ideological tensions with which land-grant university leaders must still contend, and through historical analysis illustrates key elements in their past successful navigation. Recognized today more often for his fraternal relationship to the 34th President of the United States, this paper argues that Milton Eisenhower, four times a university president and a long-time public servant in his own right, is a leader from whom much can be learned. It is argued, furthermore, that today's public highereducation leaders face challenges similar to those faced by Eisenhower, the resolution of which will determine whether the democratic heritage articulated in the Morrill Act of 1862 is preserved or abandoned.

Keywords: Milton S. Eisenhower, land-grant university, Morrill Act of 1862, public higher education

\section{INTRODUCTION}

'One of the happy tasks of a Governor of Kansas is to represent all of the people of the state at an occasion such as this. For here today we rededicate ourselves to one of the fundamentals of our democracy - free education.'

Andrew Frank Schoeppel, Governor of Kansas, September 30, 1943, speaking at the Inauguration of Milton S. Eisenhower as the 9th President of Kansas State College ${ }^{1}$

American land-grant institutions of higher learning are, and have always has been, precarious experiments (Geiger and Sorber 2013). The 106 US land-grant colleges and universities - from Cornell to Colorado State - may be viewed as democratic institutions of higher learning uneasily shoe-horned into class society. ${ }^{2}$ No other type of national research university has been, by virtue of origin and mission, so manifestly

1. A transcript of Governor Schoeppel's remarks and similar materials are available at Special Collections, University Libraries, Kansas State University. Special thanks are due to Dr David Vail, historian and archivist, formerly of Kansas State, for his assistance in assembling Milton S. Eisenhower's papers from various University Library sources.

2. Land-grant institutions are mainly, although not exclusively, public research universities $\grave{a}$ la Michigan State, Ohio State, Maryland, Wisconsin, Purdue, and Penn State. The original group defined by the Morrill Act of 1862 was augmented in 1890 and again in 1994. For present purposes, however, my focus is on the original '1862s,' as they are known, which usually serve many thousands of students and feature colleges of agriculture and engineering, extension 
burdened by the resulting tensions, even contradictions, between classically liberal and democratic tendencies in American society and culture, where, as Alan Wolfe (1977, p. 7) has noted, 'liberalism denies the logic of democracy and democracy denies the logic of liberalism.' It is important to recall that US land-grant universities were created in the midst of the American Civil War in order to render affordable as well as culturally inviting the highest quality liberal $^{3}$ and professional education, albeit for non-elite citizens, and to conduct modern scientific research and disseminate the benefits of such, albeit expressly for the public good. This democratic mission - its success to be measured, no less, than by broad-scale upward social mobility and a world increasingly governed by reason and freedom - lies in pronounced conflict with the normal workings of unfettered class society, which produces economic, political, and cultural inequalities as though by impersonal natural law, albeit alongside unprecedented liberties (and hence classical liberalism) for individuals wealthy enough, and powerful enough, to command them. The land-grant motto could be 'access to excellence' for the individual and 'democratic education for democratic society' for the public (Ross 1942; Foner 1970 [1995]).

This mission and purpose, so stated, may seem consistent with mainstream American political ideology. In fact, deep-seated, formidable opposition is arrayed against it, an opposition which prefers that access to quality higher education be reserved for those who can (manage to) afford it. In this classically liberal vision, higher education is a commodity like any other, not a political or human right nor even prudent investment in the public good. In this view, which is usually not so baldly stated, the citizenry should be as educationally as it is economically stratified. In this view, which has achieved ascendency although perhaps not outright hegemony, higher education's leaders, like government leaders, should refrain from interference in the workings of modern class society, a class society which is implicitly posited, as in eighteenthcentury physiocracy, as an ordre natural (Steiner 2003). Higher education should subordinate itself to class society, not militate against it. Higher education should subscribe to laissez-faire, even if compromises which serve industry and government interests, or which offer convenient fig leafs (relatively few modestly funded scholarships, say) for systematic reproduction of stratification, are to be celebrated. In this view, higher education exists by and for elites and to serve their interests, yet with opportunity available for select non-elite students, should their bootstraps prove sufficiently strong.

President Abraham Lincoln signed the Morrill Act into law on July 2, 1862. While it is widely known that Lincoln's own bootstraps were remarkably strong, many have conveniently forgotten his abiding and forthright preference for democracy over liberalism. Consider that, in his first annual message to Congress in December of 1861, the newly elected president stressed that 'Labor is the superior of capital, and deserves

divisions, veterinary medicine, human ecology, and other professional programs alongside a range of liberal arts and sciences degree programs. So defined, Kansas State is an archetypical land-grant university.

3. For clarity's sake, allow me to briefly parse 'liberal,' which has various distinct definitions. The 'liberal' in liberal education refers to a breadth of learning in the humanities, arts, and social and natural sciences which empowers individuals to seek knowledge as an end in itself and to be self-educating throughout life, whereas in 'classical liberalism,' liberalism refers to philosophy that valorizes individual liberty and which is represented by both the US Constitution's Bill of Rights and Adam Smith's Wealth of Nations. Both usages are distinct from American or social liberalism, which refers to the amalgam of civil, political, and social rights associated with New Deal politics. 
much the higher consideration. ${ }^{4}$ In any case, the Morrill Act - or, formally, 'An Act donating Public Lands to the several States and Territories which may provide Colleges for the Benefit of Agriculture and the Mechanic Arts' - inaugurated what came to be known as 'democracy's colleges,' and Lincoln, born in a log cabin and self-educated, could not have been more pleased (Ross 1942; Eddy 1956; Nevins 1962).

Through many periods of growth and development, these colleges grew in number and, in many cases, dramatically in terms of size, influence, and prestige (Axtell 2016). In the eyes of many, US public higher education, and the land-grant institutions in particular, became the envy of the world (Cole 2009). ${ }^{5}$ But, as they say, that was then. The erosion of public financial support for public higher education, begun under the auspices of the Reagan Administration and accelerated by the Great Recession of 2008, has placed into question the sustainability of the 'people's colleges' (Smith 2013). Land-grant colleges and universities are increasingly dependent on the vagaries of the market, beholden to the needs of industry, government, and the donor class like never before, and for other reasons and in enumerable and various ways, reproducing and exacerbating as much as disrupting and unraveling social class inequalities (Brown 2015; McGee 2015). If these trends continue, land-grant institutions of higher learning may not shutter their doors per se; but they may metamorphose into land-grant universities in name only, having had no choice but to leave behind 'the people' in favor of the paying customer. ${ }^{6}$

For students of leadership, how best, then, to analyse this situation? At one level, fiscal crises and the resulting inability of states (even 'the state') to provide adequate discretionary subsidy for the public higher education of non-propertied citizens is conceivable as the result of predictable workings of increasingly 'free' or unregulated capitalist society (Habermas 1973 [1975]; 1986; O’Connor 1973; Offe 1984; 1985; Harvey 1989; Piketty 2014). At another level, however, we may identify specific actors, places, and policies - not to mention ideological motivations - which shape pertinent societal developments and which nurture a way of thinking about them in one or another direction. It is in this space where leadership studies might benefit especially from in-depth historical study - this space where human agency and institutionalized social power form historically specific history-making (Mills 1959).

In the State of Kansas - the site of this case study - Governor Sam Brownback (a distinguished alumnus of Kansas State University) and his political allies intentionally reduced state income tax rates - sometimes called 'The Kansas Experiment' - as a

4. For the full text, see http://www.presidency.ucsb.edu/ws/?pid=29502.

5. In 1904, the distinguished horticulturist, Liberty Hyde Bailey, wrote that the Land-Grant Act was the 'Magna Charta of education: from it in this country we shall date our liberties' (quoted in Peters 2013, p. 345).

6. Thomas G. Mortenson (2012, p. 1) summarized these trends in his 'State Funding: A Race to the Bottom,' in which he writes: 'Despite steadily growing student demand for higher education since the mid-1970s, state fiscal investment in higher education has been in retreat in the states since about 1980. In fact, it is headed for zero.' On expanding corporate influence, see deBoer 2015, while the National Science Foundation's 'Universities Report Continuing Decline in Federal R\&D Funding in FY 2014' (see Britt 2015) depicts trends since 1972, during which time federal $R \& D$ funds for higher education have more than tripled, with a number of leading land-grant universities receiving $\$ 500$ million to, in the case of the University of Wisconsin at Madison, $\$ 1$ billion annually. It is also the case that land-grants have, since Eisenhower's time, increased their academic selectivity, enrolled students from higher-income groups (although still educating more lower-income students than comparable private universities), and enrolled larger numbers of students from abroad. See Sternberg 2014; Leonhardt 2017. 
hoped-for spur to entrepreneurship, business development, and increasing employment (Frank 2004; Judis 2014; Suellentrop 2015; Abouhalka 2016; Drum 2016; Levitz 2016; Weissmann 2016). This policy strategy may have also sought, perhaps in a reading or, as it were, misreading of President Reagan's 1980s tax cutting legacy, to 'starve the beast,' that is, to reduce the size of government as such (Corn 2011). By pursuing this classical liberal agenda, which views government not as the solution but, as Reagan famously stressed in his first inaugural, as 'the problem,' Governor Brownback and his allies were participating in a long tradition in US politics which dates at least to the nation's founding. In practical terms, the resulting decreases in state tax revenue translated, as though automatically, into steep reductions in governmental allocations for Kansas Board of Regents universities, community colleges, and technical schools. Alongside this material result, some of the Governor's political allies also promoted the idea that Kansas's K-12 public schools were better understood as 'government schools,' hoping to sunder, linguistically at least, the ties between a democratic citizenry, their duly elected representatives, and publically spirited institutions for the education of Kansas's newest citizens (Bosman 2016). ${ }^{7}$

The timely and more specific leadership question is thus: in such a context, how should educational leaders - and the leaders of land-grant universities, in particular - respond to these developments? How can they sustain their democratic mission in a time of declining public support, financial and otherwise? Indeed, how might my own institution, the venerable Kansas State University, best respond to its new status as a, as it were, largely self-supporting government school? Although there are any number of routes to answer such questions, I propose to examine them by looking to the past, in particular to the case of Kansas State College (later Kanas State University) under the administration of Milton S. Eisenhower (1943-1950). Marking the 75th anniversary of Eisenhower's nationally broadcast inaugural presidential address may provide helpful context and perspective to today's educational leaders. Our world has changed significantly, but in other respects surprisingly little, in the intervening century since Milton Eisenhower from Abilene, Kansas, began in 1918 as a freshman at Kansas State College. My hope is to help clarify the principal ideological conflicts faced by twenty-first-century landgrant university leaders through reflection on Eisenhower's herculean effort to bring Kansas State Agriculture College metaphorically out of the nineteenth century and quite concretely into the postwar world.

\section{MILTON STOVER EISENHOWER}

Milton Eisenhower was in many ways an unusual university president. Rather than coming to the position on the basis of academic achievement (he had earned only a BS in journalism from Kansas State), Eisenhower's pre-presidential career included, on the one hand, a close working relationship with the visionary liberal firebrand, Henry A. Wallace, then-Secretary of Agriculture, and, on the other, a prominent leadership role in the Roosevelt Administration's stunningly illiberal internment of Japanese Americans at the outset of direct US involvement in the Second World War. Likewise, Milton Eisenhower's post-Kansas State presidency was also unusual in that it included three additional university presidencies - at Penn State and twice at Johns Hopkins University - as well as steady service as an informal yet intimate and highly

7. Kansas's 'government school' advocates appear to have an ally in the Trump Administration's US Secretary of Education, Betsy DeVos (Henderson 2016; Stewart 2016; Zernike 2016). 
influential adviser to his older brother during Dwight David Eisenhower's two terms as the 34th President of the United States. Indeed, as a special envoy, member of various national commissions, leading higher-education administrator, and Republican Party activist, Milton Eisenhower enjoyed a lengthy and influential public and political career, at many times quite independently of that of his more famous older brother (Eisenhower 1963; 1974; Ambrose and Immerman 1983; Quiring 1986).

Parallel in some ways to Robert F. Kennedy's role vis-à-vis President Kennedy, or, say, Victor Reuther's vis-à-vis Walter Reuther, Milton assisted his older brother - to what exact extent is unknown - in numerous delicate matters, including drafting President Eisenhower's famous Farewell Address to the Nation in 1961, in which the President warned of the growing and diffuse anti-democratic influence of the so-called 'military-industrial complex' as well as its threat quite specifically to 'the free university.' 8 It may be safely assumed that Milton Eisenhower was, as in the title of Ambrose and Immerman's book-length hagiography, an 'educational statesman,' but it is also clearly the case that he was a statesman in the usual vein as well. One implication is that Milton Eisenhower no doubt felt an obligation - including sometimes a familial obligation - to maintain confidentiality concerning select facts and events which were part and parcel of his often sensitive public service. One must interpret his actions and what he had to say about them, even in retrospect, in light of his participation in the highest circles of national power and responsibility.

This point notwithstanding, the arch of Eisenhower's biography is easily knowable. Milton Stover Eisenhower was born on September 15, 1899, the sixth son in a relatively poor Abilene, Kansas, family that would be made world-famous by the exploits of Milton's older brother, Dwight. For his part, Milton graduated first in his high school class and, after what might today be called a 'gap' experience with Chautauqua, entered Kansas State College as a relatively mature and serious student ready to dedicate himself to the study of journalism. Crucially, Milton became a protégé of the college president, William M. Jardine, which was perhaps the single most important factor, beyond his own efforts and talents and apart from Dwight's subsequent prominence, in Milton's subsequent rise. Upon graduation, Milton took the foreign service examination. According to Ambrose and Immerman (1983, p. 37), he 'finished first,' which led to a telegram no less than from US Secretary of State Charles Evans Hughes and an offer to post at the US Consulate in Edinburgh, Scotland. Rather than stay on at Kansas State as an instructor, Jardine insisted that Eisenhower accept the offer, which he did, as though dutifully checking off 'international experience' on an invisible public service résumé.

The next major step in Milton Eisenhower's advancement was directly sponsored by Jardine, who, in 1925, had been appointed US Secretary of Agriculture. Jardine invited Milton to join him on his staff in Washington, DC, and Milton Eisenhower subsequently became a fixture at the US Department of Agriculture from 1928 to 1942. During this time, as noted, Eisenhower came to work closely with one of the most left-leaning and intellectually adventurous political figures in US history, Agriculture Secretary Henry A. Wallace (who subsequently served FDR as the 33rd Vice President of the United States, 1941-1945, and who is not to be confused with his father, Henry C. Wallace, who also

8. See Milton S. Eisenhower's obituary in The New York Times (http://www.nytimes.com/1985/ 05/03/us/milton-s-eisenhower-dies-at-85-served-as-adviser-to-president.html?pagewanted=all), as well as Milton Eisenhower's January 7, 1961, handwritten comments on the draft text of the speech, which is available online at https://www.eisenhower.archives.gov/research/online documents/farewell_address/1961_01_07_Draft_of_Speech.pdf. The address itself is readily available, although its origin and significance, even today, remains debated. 
served as Secretary of Agriculture, 1921-1924). Eisenhower was also during this period a close colleague of the famed Rexford Tugwell, Undersecretary of Agriculture and one of the most prominent and influential members of the New Deal brain trust (Katznelson 2013). Moreover, having been introduced by Wallace, Eisenhower was even befriended by President Franklin D. Roosevelt himself, who would on occasion invite Milton to private lunches in the Oval Office. As Ambrose and Immerman (1983, p. 52) note, his access to President Roosevelt made Eisenhower, independent of Dwight's meteoric rise through the general ranks, 'the envy of nearly every civil servant - and many of the politicians - in Washington.'

What happened next set in motion Milton's return to academia. On March 10, 1942, Eisenhower was summoned to the White House from Tennessee, where he was on tour as part of his duties in the Department of Agriculture. It is worth quoting Ambrose and Immerman's (ibid., p. 59) retelling of the subsequent interaction:

Hardly looking up from a document he was studying, Roosevelt said, 'Milton, your war job, starting immediately, is to set up a War Relocation Authority [WRA] to move the JapaneseAmericans off the Pacific coast. I have signed an executive order which will give you full authority to do what is essential. ... The president looked back at the paper he was reading. Eisenhower, realizing that the interview was over, turned to leave. 'And, Milton,' the president called out him, 'the greatest possible speed is imperative.'

And so it was that Milton Eisenhower began what he later readily and repeatedly acknowledged was his most regrettable government service, in which he persisted, not coincidentally, only some 90 days before resigning. Having toyed with the possibility of university leadership at an earlier juncture, the distaste for his WRA work propelled Milton, first, to the Office of War Information, and soon thereafter to Manhattan, Kansas, where he became the first alumnus offered the presidency of Kansas State College.

\section{THE INAUGURAL ADDRESS}

Eisenhower studied journalism, was an expert in mass communication, and was a professional speech writer for Agriculture Secretaries Jardine and Wallace. Not unlike his brother, Ike - and, in fact, often in direct conversation or correspondence with him Milton was throughout his years of government service steadily in touch with developments throughout US society, including in higher education. ${ }^{9}$ Indeed, one of Milton's friends during this period was Harvard University president, James B. Conant, who, in particular, influenced Milton's thinking about general education, a view which was later fleshed out in Harvard's famous 'red book' (Harvard Faculty Committee 1945; Ambrose and Immerman 1983). So, too, was Milton Eisenhower knowledgeable and apparently admiring of Robert Maynard Hutchins's 'Great Books' approach at the University of Chicago (Walker 1986). Both influences were to become evident in Eisenhower's innovations at Kansas State. But before he engaged the Kansas State community in specific proposals for reform and innovation - of which there were many to consider - Eisenhower was offered the opportunity to

9. For his part, Dwight D. Eisenhower, it should be recalled, would serve as President of Columbia University, officially from 1948-1953, although the General was on leave as the inaugural NATO Supreme Commander or campaigning for president of the United States for much of the last three years of his term. 
have his inaugural presidential address broadcast coast-to-coast via radio's 'Blue Network.' Speaking on campus, Eisenhower's words were surprising and challenging for his 1943 audience, just as they might be today. As such, they deserve careful attention. ${ }^{10}$

Eisenhower began by locating himself as a member of the 'generation of 1918,' which, as noted previously, was the year Milton entered Kansas State as an undergraduate student as well as, of course, the year of the Armistice of Compiègne. From this vantage, and setting out his principal theme, Eisenhower recalled that those "who entered this College in 1918 developed the notion that civilization had become a race between the machines of man and the wisdom of man' (p. 263). Here, Eisenhower presented his audience with an implicit analysis of alienation under conditions of modern mass society. The cherished ideals under threat - which Eisenhower presented, probably strategically, as though widely and generally accepted - were those of philosophical pragmatism, political democracy, and social progressivism. Echoing Lincoln and John Dewey, Eisenhower stated:

Above all else, we have a faith in people - in their virtues and in their potentialities. We therefore hold that human beings are more important than the institutions they create. We will not permit any institution or system of whatever political, economic or military complexion to become our master. We believe government must be of the people, by the people and for the people, if the sciences of peace are to contribute to human betterment. (p. 264)

As for Milton Eisenhower's progressivism, perhaps there is more than a hint of Theodore Roosevelt in his statement a moment later that 'Any institution or civilization which fails to fight vigorously to push back what is still a vast area of darkness [human ignorance - SPD] will decay' (p. 265).

Where alienation comes in is already implied in his statement of what is to be valued and protected: the fruits of science and of modern human advancement have come to endanger the very way of life that produced them, including its individual freedoms, political democracy, and its orientation toward the progressive amelioration of social problems by means of scientific progress. Scientific advancement requires specialization, but this same specialization leads to fragmentation and fissures in common understandings and thus perhaps to technocracy, rather than democracy, that is, a social order ruled by the tyranny of the specialist rather than the informed will of the people. Scientific advancement also leads to an extraordinary increase in power over nature, but to what ends and used by whose decision? As Eisenhower notes, 'Two wars in one generation have convinced many people that knowledge, even though widely diffused, is not in itself enough to guarantee these goals [namely, 'a fuller life in an environment of individual liberty and social justice']' (p. 265). He stresses:

... I do mean to say that the fruits of science and technology cannot, in themselves, automatically instil into us the wisdom, the tolerance, the integrated reasoning required for the management of individual and organized affairs in a complex and rapidly changing civilization. (p. 265)

Having identified himself as a member of a generation which had, evidently and admittedly, failed to establish and secure a sustainable system of peace and prosperity, Eisenhower indicated his view that ' $[\mathrm{t}]$ he generation which goes forth into a peaceful world when this war is won will face problems infinitely more complex than ours

10. The address is rendered as appendix A in Ambrose and Immerman (1983, pp. 263-269). All page citations are to this text. 
when we left College at the end of the last war' (p. 266). This much appeared selfevident to Eisenhower's audience in 1943, even before the Manhattan Project would make the proposition seemingly incontrovertible.

What, then, should be Kansas State College's role in the postwar world? What of the land-grant universities as a group? Eisenhower gets to the meat of his argument:

It will not be enough for a man to know how to build Grand Coulee dam or the Golden Gate bridge. It will not be enough for a man to know how to till the soil and protect it. It will not be enough for a man to know how to heal the sick. For every man with a useful place in society will have several great responsibilities. He will have the responsibility of using his specialized talent to make a living for himself and his family. As a citizen in a democracy, he will often have the responsibility of applying his specialized talent to the solution of community, state and national problems within his field of special competence. And as a citizen in a democracy, he will always have the responsibility of making manifold decisions on complex problems outside his own discipline - decisions which, if made in ways compatible with our democratic methods, can spread the blessings of democracy, strengthen democracy, and guarantee its future. (pp. 266-267, emphasis added)

Emphasis is given to the last formulations because it is the heart of Eisenhower's overarching idea and the basis for his most important educational reforms at Kansas State. For Milton, technical schools and colleges like Kansas State have an even 'greater responsibility' than liberal arts schools to provide for 'integrative' learning because 'in our technical colleges we specialize in scientific disciplines and we therefore face the danger of encouraging a man to become a specialist within one discipline, and a dogmatist in affairs within other disciplines' (p. 267). The solution posited is integrative general education and skills in interdisciplinary communication; for Milton Eisenhower, ' $[\mathrm{m}]$ ost human misunderstandings stem from a failure of the disagreeing parties to consider objectively the same set of relevant facts and then to reason from those facts toward an agreeable solution,' adding a moment thereafter, 'I have no doubt that the land-grant colleges as a group will function in this regard' (pp. 267-268).

Speaking from the heart of the heartland in the midst of US direct involvement in the Second World War, with the wars in Europe and the Pacific not yet even at their most fevered pitch, Milton Eisenhower anticipates that the land-grant university - Kansas State College a leader among them - will be on the next critical front in the ongoing struggle for a peaceful modernity worldwide. 'A victory of arms ... is not the end for which we fight,' he states (p. 264). To preserve 'human dignity and freedom' (ibid.), Eisenhower instead urges 'technical schools and colleges' (p. 267) to embrace the need not only to produce and disseminate scientific knowledge, but also to cultivate 'wisdom,' 'judgment,' and/or 'integrative reasoning' (p. 265; Eisenhower uses these terms interchangeably). Not only to defeat the Axis Powers, but also the alienation of reason and freedom under conditions of capitalist modernity, Eisenhower imagines that '[d]emocracy will endure only if responsible citizens are able to arrive at sound judgments in a great multitude of fields,' instituting a prevailing democratic social and cultural condition in which 'human knowledge is matched by human wisdom' (ibid.).

From a contemporary vantage, and recalling Milton's involvement in the writing of President Eisenhower's farewell address in 1961, we might observe that this would not be the first time that Milton's words echo those which could be just as easily, and surprisingly, associated with the likes of C. Wright Mills, the author of such American sociological classics as White Collar (1951), The Power Elite (1956), and The Sociological Imagination (1959). The last work, in particular, is a call for the cultivation of a 'quality of mind' which can skillfully 'grasp history and biography and the relations 
between the two within society' (Mills 1959, pp. 5, 6). Mills, like Milton Eisenhower, viewed this quality of mind as essential for democracy in highly stratified, complex capitalist-industrial society, where democracy 'implies that those vitally affected by any decision men make have an effective voice in that decision,' and where the role of the educator is to 'cultivate such habits of mind among the men and women who are publicly exposed to him' (ibid., pp. 188, 187). So much surface consensus obtains that one might be hard pressed to discern which of the two, Milton Eisenhower or C. Wright Mills, was the author of the following summary:

Our concern is that men shall conquer machines, that machines shall not conquer men. Our concern is that men and women trained in scientific methods shall also gain tolerance, and understanding, and wisdom. Our concern is with the education of men and women determined to be free. (Ambrose and Immerman 1983, p. 268)

Nothing is known about the reaction among Blue Network listeners nationally, but the reception to Eisenhower's speech within the campus fieldhouse was reportedly mixed. As Ambrose and Immerman remind us, Manhattan, Kansas, was located then as now in a primarily conservative region. Eisenhower's immediate predecessor, Francis David Farrell, who served as Kansas State College's president from 1925 to 1943, was so conservative that 'he had refused all New Deal assistance' for the college (ibid., p. 76), a move parallel to some contemporary Republican governors, Kansas Governor Brownback among them, who have refused on principled ideological grounds the federal financial assistance associated with the Affordable Care Act's expansion of Medicaid. 'The audience in the old auditorium had come expecting much ceremony and little content,' write Ambrose and Immerman (1983, p. 77). 'Nearly all its members were surprised. By no means were all pleased' (ibid.).

Based on a 1980 interview with Milton Eisenhower himself, Ambrose and Immerman (ibid., p. 78) write: 'This brash young man had perhaps had too much contact with FDR and other Ivy League types back in Washington. He needed to be reminded that Kansas State's task was to produce more grain, not more intellectuals, better cows, not better humanists.' Regarding his motivation, Eisenhower told Ambrose and Immerman that engineering and agricultural students were especially, in his view, in danger of being 'ignorant of the social sciences, the humanities, and the liberal arts [sic]' (ibid., p. 79). Given Eisenhower's perspective, this was no mild deficit; rather, such ignorance was tantamount to their being denied the education they needed, the education that was generally required for democracy to thrive, or at least survive, the alienating contradictions of the modern postwar world. As Eisenhower had stated in his inaugural address: 'There can be no real freedom without sound education. There can be no true education without freedom. The two are inseparable' (p. 267). With a nod toward the multitudes of returning veterans soon anticipated from the far-flung theaters of the Second World War - and, no doubt, to ground his perspective in their many extraordinary sacrifices Milton Eisenhower argued that these veterans of world-wide war would want to know, and would need to know, what 'they fought for' (p. 267). His implication is that the answer had better not be: for superior farm implements.

\section{REFORM OF KANSAS STATE COLLEGE}

In his reflections on Eisenhower's administrative leadership of Kansas State College, Russell I. Thackrey (1986, pp. 59-60), then-Executive Director Emeritus of the National Association of State Universities and Land-Grant Colleges and formally 
Dean of Administration under Eisenhower (1944-1947), enumerates seven areas where Eisenhower began or himself achieved important administrative innovations: (1) he helped create an endowment association which could borrow when the University, constrained by state law, could not; (2) he helped create a faculty senate; (3) he helped create an annual artists' series and (4) became chair of a Friends of Art association; (5) he helped institute the tenure system; (6) he improved faculty morale through an emphasis on public communication and administrative transparency; and (7) he took it upon himself "quietly but firmly to eliminate on-campus [racial] discrimination,' as well as in intercollegiate sports and in the Manhattan community. ${ }^{11}$ As obviously important as each of these were and are, Eisenhower's signature innovations are in addition to the above. They were, as noted, the 'comprehensive' general education curriculum, which presaged what Harvard would advocate in its famous General Education in a Free Society (Harvard Faculty Committee 1945), and the establishment of the Institute for Citizenship, which was modeled with Eisenhower's full and active support on the University of Chicago's Great Books curriculum by its inaugural director and University of Chicago alumnus, Robert A. Walker. ${ }^{12}$

If integrative learning was essential and, indeed, urgently needed in the postwar world, then Kansas State College would have to find a way to teach across and beyond disciplinary specialties. What Eisenhower proposed, and what, after some considerable confabulation and debate, was agreed to, were four courses - Man and the Humanities, Man and the Social World, Man in the Physical World, and Man in the Biological World - exactly what would be proffered as a standard by the Harvard authors of General Education in a Free Society, writing, as they did, under the imprimatur of President Conant. As suggested by their titles, the point of these courses was to provide broad integrative learning in the humanities, social, biological, and physical sciences, especially for non-majors. Students majoring in one of the four areas were excused from the comprehensive course in that area on the logical assumption that general knowledge would be introduced as a component of disciplinary specialization. The target audience, of course, were those students whose specialization did not, or would not necessarily, include a breadth of learning which included the liberal arts. In this, Eisenhower was only revisiting the original language of the Morrill Act of 1862 , which was explicit concerning the 'liberal and practical education of the industrial classes in the several pursuits and professions in life.' As Ambrose and Immerman (1983, p. 79) note, Eisenhower 'confessed decades later, "At the time I was a little enamored of what's called comprehensive courses".'

Not all Kanas State faculty were so enamored. Then and now, the hegemony of positivist science militates against integrative reasoning; specialization, even hyper-specialization, produces disciplinarily and sub-disciplinarily article-length results and attendant material and symbolic rewards, while scientific research (and published evidence of scholarship of any kind) usually outweigh - often significantly so - teaching excellence and service to community, university, discipline, and

11. Ambrose and Immerman (1983, p. 105) note that Eisenhower declined an offer to serve as president of the University of Tennessee, writing to Ike that 'I do not feel that I would be happy or effective in a southern state.'.

12. To underscore the quality of individuals involved, it is worth noting that, in his postKansas State career, Professor Walker 'presided over undergraduate education at Stanford [University] in the late '50s and '60s and co-founded the university's very popular overseas studies program ...' (quoted in Walker's official February 9, 1998, Stanford University obituary, available at: http://web.stanford.edu/dept/news/pr/98/980209walker.html). 
profession. This implicit academic hierarchy existed at Kansas State College in 1943 just as it does at most, if not all, national research universities today. The very thought of specializing in general knowledge - this, with a mind principally toward producing that which might be deemed examples of 'wisdom' for the benefit of students, especially undergraduate students in introductory courses - seems at once entirely reasonable and entirely fanciful. Eisenhower's plan is and was plainly outside the dominant academic ethos of the modern research university, the many laudable attempts to reform the dominant situation as well as the countless faculty who regularly strive against this prevailing ethos in favor of an ethically defensible relationship with their students notwithstanding. Ambrose and Immerman quote various individual points of view in the immediate aftermath of Eisenhower's push to have his program adopted, including the Kansas State College dean of home economics, who told them that 'Milton Eisenhower used democratic means to achieve his dictatorial ends' (ibid., p. 80), and an unusually liberal member of the university community who would come to serve Eisenhower as an assistant, who explained: 'He [Eisenhower] imposed this stuff on a faculty that was incompetent to handle it and which resented having it imposed' (ibid.). Soon after he left for the presidency of Pennsylvania State University, the Kansas State College faculty discontinued Eisenhower's pioneering 'comprehensive courses,' a move which foreshadowed subsequent decades of debate over the proper scale and scope of general education at US research universities, even at Harvard University (Menand 2010).

For its part, Kanas State's Institute for Citizenship experienced a similar postEisenhower fate, but was no less innovative or productive regarding future developments. Imagine Kansas State students in the late 1940s reading The Communist Manifesto and Milton's Areopagitica? Such is what Walker's Institute for Citizenship curriculum required. Eisenhower had secured a $\$ 200,000$ donation from the William Volker Charities in Kansas City, Missouri, with the intent to create an interdisciplinary, original text approach to courses such as 'Freedom and Responsibility' and in such areas as 'law and justice, war and peace, government in economic affairs, and education in democratic society' (Ambrose and Immerman 1983, p. 98). According to Ambrose and Immerman, the faculty would eventually be composed of professors of philosophy, economics, education and the natural sciences. Professor Walker, who Eisenhower personally pursued and eventually successfully recruited for the directorship, was himself a political scientist.

When Walker arrived in Manhattan in November of 1945 to begin the planning of the Institute, there was, however, no department of political science. Walker welcomed this, for it spared him from having to even consider the 'obvious approach to the education of citizens,' that is, 'the usual courses in American government, parties, and pressure groups; state government; public administration, and so forth' (Walker 1986, p. 71). As Walker (ibid.) recalled years later:

Rather than falling quietly into the textbook and quiz routine, which such an approach would have invited, I was determined that we would use the original writings of those who had contributed most to the great political debates. These are far more interesting than textbooks, while active discussion and comparison of their contents requires thought. Thus discussion, not lectures, was to be the keynote of the program.

As so it came to pass that students were offered the opportunity to read Adam Smith as well as Karl Marx, and, upon reflection and through discussion, arrive at their own conclusions. Walker found little expression of disquiet much less calls for censorship in the larger community, even when such courses were offered off the Manhattan 
campus as part of adult education. But there was, ironically, angst among the Kansas State College faculty, who, according to Ambrose and Immerman, resented Institute faculty's emphasis on multidisciplinary approaches as well as their elevated pay, and who, at least in one instance, expressed the feeling that 'the original-writing approach was all nonsense' (Ambrose and Immerman 1983, p. 98; Walker 1986, p. 73).

Thus, it is perhaps not surprising to learn, in Ambrose and Immerman's (1983, p. 98) blunt formulation, '[w]hen the funding from the Volker Fund ran out, and after Eisenhower left Kansas State, the institute collapsed.' But, as Ambrose and Immerman also note, many of the Institute's most popular courses were absorbed into what would become College of Arts and Sciences departments. Thackrey characterized Eisenhower's Institute for Citizenship legacy this way: its 'real effect in the long run was that it developed a substantial program in the areas of political science, theory, etc., which had been completely nonexistent before' (Ambrose and Immerman 1983, p. 98). Many years later, Kansas State University would establish a School of Leadership Studies, offering interdisciplinary courses that foster and facilitate various forms of domestic and international civic engagement (Chrislip et al. 2016). The import and influence of the Mary Lynn and Warren Staley School of Leadership Studies, as it is known, is reflected in the fact that roughly one in four Kansas State first-year students enroll annually in the School's course in 'Introduction to Leadership Concepts.'

While president of Kansas State College, Milton Eisenhower availed himself of abundant opportunities to share such good news from Manhattan, Kansas. He was appointed by President Truman to the Commission on Higher Education; he was elected to the executive committee of the Association of Land Grant Colleges and Universities (including to its chair in 1946); he served as chair of the US National Commission for UNESCO; he was appointed by Truman, along with Lloyd Garrison and Matthew J. Connelly, to mediate a national UAW strike against General Motors; and he served on the Famine Emergency Relief Commission as well as advised the US Department of Agriculture on a reorganization (see Ambrose and Immerman 1983, p. 104). As Walker (1986, p. 77) notes, '[b]y 1948 there was a growing sentiment among the deans and faculty that he [Eisenhower] was spending too much time away from the college. It was also my personal perception that his mounting national stature was likely to take him away from Kansas State.' And in 1950, the trustees of the Pennsylvania State University would do exactly that.

\section{CONTEMPORARY IMPLICATIONS}

In his foreword to The Undergraduate Experience: Focusing Institutions on What Matters Most (Hrabowski 2016, p. x), Freeman A. Hrabowski III, the renowned President of the University of Maryland, Baltimore County, writes that today's higher education leaders need 'optimism ... more than ever.' 'Every generation in higher education has faced challenges and opportunities,' he writes, which today include 'globalizing social and economic context, shifting fiscal challenges, changing demographics, accelerating technological change, and advances in teaching and learning' (ibid.). Amid such change and tumult, what is most needed, Hrabowski argues, is the 'positive restlessness' to 'think about our own institutions, leadership styles, and visions, with the hope that these stories can strengthen our resolve to change and turn our visions into the desired reality' (ibid., emphasis added).

Coincidentally, stories, not to mention positive restlessness, are also central to Scott J. Peters's (2013) reflections on today's land-grant university. Professor of the Cultural 
Foundations of Education at Syracuse University and co-director of Imagining America: Artists and Scholars in Public Life, Peters follows Alisdair MacIntyre (1981) in thinking that, no matter how rigorously self-critical and scientific in approach, human thought can never escape having to implicitly locate itself amid possible non-rational sets of background assumptions - possible stories - from which all forward-thinking action must derive an often critical element of orientation. Or, put more simply, Peters believes that we choose our history as antecedent to choosing our future. Again, this is not appreciably different from what C. Wright Mills proposed in The Sociological Imagination (1959), except perhaps that Mills, a sociologist, laid more emphasis on also selecting one's vision of social structure, which is the principal means through which history, as it were, is made. For his part, Peters's study of the existing historiography of land-grant universities allows him to discern competing narrative forms the heroic, tragic, and prophetic - all of which, he thinks, have solid evidence to support their respective competing claims, but none of which is thereby exclusively true. Thus, Peters (2013, p. 348) cautions:

... historians and scholars of the land-grant system will need to develop keen sensitivity to complexity and contradiction, and to the significance of values and perspective in shaping and guiding particular ways of setting scenes and emplotting and interpreting events and actions. They ... will need to learn to tell more complex stories that address erasures in previous works, incorporating new and different perspectives and neglected characters and events that enable us to see and care about the land-grant system in new ways.

In 'storying,' as I have, Milton Eisenhower's presidency of Kansas State College, what implications, then, have I surfaced over and against others possible? What lessons might today's land-grant university leader draw from Eisenhower's leadership at Kansas State, or even, for that matter, for Kansas State?

It may help to recall briefly the year 1943. In its first months, Nazi forces encircled Stalingrad but were ultimately defeated in an especially bitter struggle, while Roosevelt, Churchill, and de Gaulle met in the Anfa district of Casablanca to plot a strategy to end the war. The former battle helped turn the tide of war in Europe, while Allied leaders were able to convene where they did because Milton Eisenhower's brother had successfully led the Allied invasion of North Africa. By May, the Warsaw Ghetto uprising was broken and little resistance remained to the full prosecution of Hitler's 'final solution,' whereas in areas of the world not terrorized daily by mass death and genocide, a certain normalcy emerged: in May, for example, Winston Churchill addressed a joint session of Congress. By September, the month in which Milton gave his radio address to the nation from Kansas State College, General Eisenhower announced the surrender of Italy to Allied Forces. And, by December, with one Eisenhower now firmly ensconced in Kansas State's Anderson Hall and the Great Depression in the US officially declared as over, another Eisenhower was named Supreme Allied Commander Europe and looked ahead to the planning of D-Day. Milton's general education and citizenship-oriented reforms may seem small set in the context of worldwide conflagration. But, if they were trivial, then why were his efforts so often resisted, and, at the first opportunity, discontinued?

No doubt Eisenhower's status as an alumnus and experienced Washington insider, not to mention brother of an emerging war hero, helped his cause vis-à-vis Kansas State faculty and other key constituents; no doubt the support Milton continued to receive from former Kansas State College president, William Jardine (who had gone on to the presidency of what would become Wichita State University), also helped (as did the honorary doctorate which Jardine's Municipal University of Wichita bestowed 
upon Milton); that Milton Eisenhower was bringing ideas and practices to Kansas State which were cutting-edge at Harvard and Chicago must have helped bolster Milton's own confidence that his proposed reforms were worthy of implementation. And, no doubt, Eisenhower's familiarity with, even comfort with, a wide range of political ideologies, from Henry A. Wallace's democratic populism to Milton's own homespun Kansas Republican progressivism, must have made his reforms seem, at least to himself, eminently fair-minded, perhaps even commonsensical, and certainly far from more radical possibilities.

Perhaps most importantly but also most often overlooked, having been intimately involved in the gruesome details of the forced internment of Japanese-Americans, even if for only a three-month period (Yamamoto et al. 2013; Reeves 2015), Eisenhower must have approached the reform of the College's curriculum with a special sensitivity and sense of urgency (even if wartime secrecy and security concerns may well have prevented him from expounding on this fact), for his ultimate purposes could be easily construed as to position higher education, and Kansas State College as an exemplar, as an antidote to such notorious (un-Constitutional, alienating) undertakings. Eisenhower no doubt wanted to help make such events unrepeatable, or at least far less probable, in postwar America. Imagine Eisenhower's Institute of Citizenship, then, not as a cynical proto-Cold War gambit (although this is no doubt part of its appeal), but as a bulwark against the threat of domestic authoritarianism; it was arguably as anti-fascist, then, as it was anti-communist.

Today's educational leaders make their way in similarly harrowing times and face similar concerns. From global climate change, in all its extraordinary dimensions, to what seems a postmodern 'Twitter' authoritarianism emergent in the US and elsewhere (Ross 2016), the education provided at today's land-grant university cannot, and must not, valorize specialization and hyper-specialization at the expense of general education and citizenship development, lest it cede public discourse and popular decision-making the stuff of democracy - to the vagaries of balkanized mass media, propaganda, class antagonism, and class-based resentment. ${ }^{13}$ Today's world seems to cry out for democratized and democratizing higher education. To meet this demand means tailoring higher education to the needs of today's students, among them veterans, yes, but also a larger and much more culturally diverse, non-traditional, and socially fragmented and psychologically challenged student population. This also means resisting the privatization of higher education, which, in one facet, treats the general education curriculum as an expensive and expendable tax on the world-be student-careerist, courses to be 'gotten out of the way' as though they are nothing but obstacles to what is valued and sought after. ${ }^{14}$ If nothing else, surely Eisenhower's example should caution against commodifying and bureaucratizing tendencies in higher education (Tuchman 2009), which devalue the human relationship between student and professor in favor of technologically driven 'disintermediation' of student and 'course content,' arguably a victory of 'the machines of man' over 'the wisdom of man' if there ever was one (Christensen and Eyring 2011; Selingo 2013; Carey 2015; Craig 2015). The Morrill Act, its interest in applied research and education notwithstanding, did not presage diploma mills churning out narrowly credentialed technicians incapable of leadership in their own lives, let alone in relation to fellow citizens.

Consider also the theoretical sophistication evident in Eisenhower's inaugural address, the small sections quoted herein an injustice to its eloquence. Eisenhower

13. For an assessable presentation of critical social science data, see Amanda Taub (2016).

14. For one pointed example of this view, see Scott Jaschik (2016). 
may have served in a number of civil service roles, but he was never a bureaucrat. He may not have earned an advanced research degree, but he was a gifted intellectual who read Greek, studied history, and was deeply knowledgeable of, as well as of course immersed in, public affairs. His true 'specialty,' however, such as it can be construed as a narrow field at all, was communication. It was for good reason that Eisenhower served as associate director of the US Office of War Information and played a similar role at the US Department of Agriculture: he was a highly skilled practitioner of journalism and mass communication. Knowing what most needed elucidation as well as how best to effectively communicate such was not only what Eisenhower wished for every land-grant undergraduate, regardless of major, it was also what he took from his own undergraduate experience. One imagines Milton's private discussions with Ike concerning the President's farewell address; it is as though he were writing a review of C. Wright Mills' The Power Elite, but for all citizens rather than for experts in political sociology, and to foster social change rather than to add a line to his vita as a fellow academic might. The land-grant leader who wished to follow in Eisenhower's footsteps might consider 'communication,' broadly understood, as a history-making enterprise, the space in which to give form and direction to what is needed and to affirm and reaffirm cherished values, especially against evident threats to their integrity and ongoing conservation.

There is then the matter of Eisenhower's character and personality. He was not, apparently, an overtly charismatic leader. Rather, Milton Eisenhower was a person of traditional conservative upbringing who was, or who had learned to be, careful and guarded, averse to conflict, confident, and subtly self-promoting, but also disinclined to too much introspection. Robert Walker, a specialist in the psychology of administrative organization as well as a $\mathrm{PhD}$ in political science, offers this anecdote:

The Eisenhowers were dinner guests in our home one evening. I had gone to the kitchen, and, as I returned, Milton was looking at a book that I had left on the table. It was Karen Horney's The Neurotic Personality of Our Time, one of the best popular books on the subject yet written. He looked up, put the book down forcibly, and said, 'My God, I would be afraid to read a book like that!' I am quite sure that he meant it. (Walker 1986, p. 77)

Walker also discusses Milton Eisenhower's aversion to full-throated confrontation with racial segregation, and the controversy it would be expected to bring, while Ambrose and Immerman, for their part, note Eisenhower's consistent disinclination to fire underperforming staff, which is inevitably stressful for both parties to the divorce. There is nothing in Eisenhower's own writings or those texts written about him - nothing I have discovered in his papers and personal documents - which hints at leadership by means of sheer force of personality, much less tendencies toward the firebrand. Still, Eisenhower was able to play the role of an establishment figure capable of leading others and of shouldering considerable responsibilities. In this role, he was an effective advocate for Kansas State vis-à-vis state legislators, in part, it would seem, because he was known to them - spoke their language, as it were - and acquitted himself with a Kansas modesty which belied his exceptional intellect and worldly experience. This product of small-town Abilene, Milton Eisenhower was a discreet, mannered, reliable, self-possessed and carefully selfcontrolled actor among (fellow) elites.

Today's land-grant leaders who might view Milton Eisenhower as a role model need not, then, live up to a superhuman precedent. His success at liberalizing the curriculum of Kansas State College did not rely on rare, much less singular, personal attributes. Instead, Eisenhower's leadership talents were primarily practical, in the sense 
that all things human are. He established committees, he curried favor with various constituents, he secured gifts, and he avoided unnecessary conflicts. But, as we have seen, Milton Eisenhower also articulated a vision, a vision, moreover, which was rooted in his own biography as well as that of the history of the nation, and he stuck to it until it was realized. It may be observed that Eisenhower's considerable ability to situate change and discuss values within larger contexts, a hallmark of liberal education, was both the means and desideratum of his leadership efforts. In the absence of the 'Blue Network,' however, today's leaders must avail themselves of whatever platforms lie in reach. Eisenhower traveled Kansas, the nation, and world, embodying Kansas State College wherever he went and spoke. But he also camped with student leaders, lived modestly, and in other ways over his career made himself accessible to, and accountable to, faculty, staff, and students.

It is important, finally, to underscore what Eisenhower did not have to do: he did not have to create a new business model for land-grant higher education, as land-grant leaders must do today. When, for example, Kansas State College was faced with the pressures of large numbers of returning veterans filling classes and greatly expanding faculty-to-student ratios, Eisenhower was able, on the one hand, to convince the legislature to provide additional funding, and, on the other, to allay faculty concern by clearly communicating the trade-offs between the needs of the students, to whom flowed considerable sympathy, and the constrained budget of the institution. Eisenhower was a frugal president; there was no question of shared sacrifice going hand-in-hand with shared governance. And the State of Kansas was at that time disposed toward investment in its public institutions of higher learning, which were then regarded as effective means for the betterment of the people's lives, those who would earn degrees as well as those who would not alike. Indeed, with the advent of the G.I. Bill in 1944 an explicit national commitment to the proposition that education is a democratic value if there ever was one - access and excellence were, as it were, squared for the next two generations to come.

As stipulated at the outset, similar alternatives and resources are largely unavailable today. In Kansas, even a sympathetic legislature and a governor fully dedicated to funding higher education would have great difficulty, if it were possible at all, in patching existing budget holes, funding mandated programs (K-12 schools, prisons, etc.), and also providing the level of support which the state's institutions of higher education need to maintain their educational excellence. The period of postwar prosperity, built as it was on the US position of dominance after the war and spurred by exceptional technological advantages accruing unprecedented benefits for Americans of all social classes, came to end in the 1970s, and with it, the liberal-capitalist 'class compromise' which made public support for public higher education, such as the G.I. Bill widely celebrated (see Wolfe 1977). The erosion of taxpayer support, most manifest in the Reagan-era policy that began the shift of the financial burden of college attendance from public grants to private loans, has continued largely unabated for the past 30 or more years. The result at Kansas State University is that the annual amount of tuition and fee revenue has eclipsed annual state support, an inversion that occurred long ago in many other states. The national trend toward zero or near-zero state support for higher education continues, leaving land-grant institutions strung between a mission to provide 'access' across the class spectrum and a need to fund, more and more from tuition and fees, scholarly and academic excellence. The Morrill Act did not, of course, envision 'access to mediocrity,' which would neither meet student or societal needs, nor, alas, make for a motivating bumper sticker. 


\section{CONCLUSION}

Given the period in which he served Kansas State - an era when Republican governors could hail the value of free education without the slightest hedging - it was perhaps relatively easy for a leader with Milton Eisenhower's ability and vision to balance the inherently competing values of liberty and equality (Burns 1978 [2010], p. 432). For Eisenhower, education was, after all, tantamount to liberty, for it freed the mind. For its part, democracy required knowledge held in common and shared points of intellectual and cultural reference such as were derived from 'comprehensive courses,' not to mention minds accustomed to working across disciplinary and professional specialties to integrate knowledge and arrive at sound and wise judgments, such as was also on offer at his multidisciplinary Institute for Citizenship. In Eisenhower's pragmatic and progressive worldview, such learning was needed by statesmen like his brother, who would be the first to command an arsenal of thermonuclear warheads and intercontinental ballistic missiles, as well as by citizens in all walks of life, like the people of Kansas, in whose soil a good number of those missiles would be planted. Public education, which brings citizens together or which, when gone off the rails, reinforces existing divisions, plays a profound role in shaping the interplay between individual liberty and social justice. Milton Eisenhower knew, as Justin Morrill and Abraham Lincoln did before him, that foreclosing access to quality higher learning except for the already privileged was tantamount to inviting the collapse of democracy itself. $^{15}$

It remains an open question whether resurrection of educational leadership in the manner and style of Milton Eisenhower - theoretically and historically grounded, but dependent, perhaps, on institutional supports and cultural dispositions of a bygone era - would be effective 75 years and more after he first became a university president. One wonders, in particular, whether Eisenhower's 'generation of 1918' brand of progressivism, with its abundantly serious but also optimistic, open-minded, and humanistic bent, is sufficiently equipped to deal with cynical and stridently antidemocratic resistance to 'government schools' and all which that dark bon mot entails. But perhaps it is. As Louis Menand has argued, the very development of pragmatism was defined in part by revulsion to the ideological divisions which had undergirded the American Civil War, and from that, to revulsion against ideologies as such. Of Holmes, James, Peirce, and Dewey, Menand (2001, p., xii) writes: 'The belief that ideas should never become ideologies ... was the essence of what they taught.' Unfortunately, ideas still become ideologies, and, too often, ideological distortions continue to cloud the higher-education leadership challenges of the day.

Just as the young pragmatists pondered the American Civil War and produced a new philosophical school, and just as Milton Eisenhower pondered the Great War and essayed against the possibility that 'institution or system of whatever ... become our master,' it may be that the 'culture wars' swirling around today's public higher education are, indeed, more threatening and set more deeply in obdurate social institutions than usually acknowledged, or than Peters's otherwise helpful attention to the 'stories' we tell about ourselves suggests. It may be that a new kind of leadership is needed, therefore - one in tune with today's globalized, neoliberal social structures, and thus prepared to resolve the endemic liberal-democratic tension internally, such

15. Recall that Milton Eisenhower had experience of watching a president, regarded as liberal and leading the so-called Democratic Party, order US citizens into concentration camps on American soil; the collapse of democracy was not, therefore, foreign to his personal experience. 
as private institutions, including the likes of Cornell and Johns Hopkins, do. Probably the most important institutional means available to university leaders is strategic enrollment management linked to intentional student-success-oriented restructuring (Hossler and Bontrager 2014; McGee 2015; Felten et al. 2016). In its liberal guise, this approach uses sophisticated economic tools to generate from tuition and fees annually available net revenue which replaces that which is lost from declining public investment, whereas, in its democratic dimension, university leaders mindful of their missions, including the land-grant mission, allocate large portions of this net revenue to need-based aid as well as to other initiatives designed to render a high-quality higher education affordable to all who need it and all who seek it. If, for whatever reason, governments fail to support democratic education for democratic society, then the leaders of 'government schools,' working through shared governance, are compelled to step into the breach.

Whether or not American pragmatism and progressivism is sufficient for this task, Milton Eisenhower's legacy deserves attention alongside Conant and Hutchins and other 'extraordinary' university presidents like Kerr, Friday, Hesburgh, Gray, Slaughter, and Bowen (Padilla 2005). Perhaps it is enough to say that US higher-education leaders, especially the leaders of cherished land-grant institutions, would do well to communicate as effectively as Milton Stover Eisenhower concerning mission, vision, and context, as well as to stay conversant, as it were, with Eisenhower's rich legacy. 


\section{REFERENCES}

Abouhalka, Y.T. (2016), 'Brownback's "Sunshine" on Tax Cuts Vanishes Behind Big, Dark Cloud,' The Kansas City Star, September 26, available at: http://www.kansascity.com/ opinion/opn-columns-blogs/yael-t-abouhalkah/article104171736.html.

Ambrose, S.E. and R.H. Immerman (1983), Milton S. Eisenhower: Educational Statesman, Baltimore, MD: Johns Hopkins University Press.

Axtell, J. (2016), Wisdom's Workshop: The Rise of the Modern University, Princeton, NJ: Princeton University Press.

Bosman, J. (2016), 'Public Schools? To Kansas Conservatives, They're "Government Schools",' The New York Times, July 9, available at: http://www.nytimes.com/2016/07/10/ us/schools-kansas-conservatives.html.

Britt, R. (2015), 'Universities Report Continuing Decline in Federal R\&D Funding in FY 2014,' National Science Foundation, InfoBriefs, NSF 16-302, available at: https://www.nsf.gov/ statistics/2016/nsf16302/.

Brown, W. (2015), Undoing the Demos: Neoliberalism's Stealth Revolution, Cambridge, MA: MIT Press.

Burns, J.M. (1978 [2010]), Leadership, New York: Harper Perennial Political Classics.

Carey, K. (2015), The End of College: Creating the Future of Learning and the University of Everywhere, New York: Riverhead Books.

Chrislip, D., J. Arensdorf, T. Steffensmeier, and M.H. Tolar (2016), 'Leadership in the Civic Arena,' Leadership and the Humanities, 4(2), 126-142.

Christensen, C.M. and H.J. Eyring (2011), The Innovative University: Changing the DNA of Higher Education from the Inside Out, San Francisco, CA: Jossey-Bass.

Cole, J.R. (2009), The Great American University: Its Rise to Preeminence, its Indispensable National Role, Why it Must be Protected, New York: PublicAffairs.

Corn, D. (2011), 'Reagan: Morning After in America,' Mother Jones, February 4, available at: http://www.motherjones.com/politics/2011/02/reagan-anniversary-david-stockman.

Craig, R. (2015), College Disrupted: The Great Unbundling of Higher Education, New York: St. Martin's Press.

DeBoer, F. (2015), 'Why we Should Fear University, Inc.: Against the Corporate Taming of the American College,' The New York Times Magazine, September 9, available at: http://www. nytimes.com/2015/09/13/magazine/why-we-should-fear-university-inc.html.

Drum, K. (2016), 'Kansas Governor Sam Brownback Wants to Wreck the US Economy Too,' Mother Jones, December 23, available at: http://www.motherjones.com/kevin-drum/2016/ 12/kansas-governor-sam-brownback-wants-destroy-us-economy-too-0.

Eddy, E. (1956), Colleges for Our Land and Time: The Land-Grant Idea in American Education, New York: Harpers.

Eisenhower, M.S. (1963), The Wine is Bitter: The United States and Latin America, New York: Doubleday.

Eisenhower, M.S. (1974), The President is Calling, New York: Crown.

Felten, P., J.N. Gardner, C.C. Schroeder, L.M. Lambert, and B.O. Barefoot (2016), The Undergraduate Experience: Focusing Institutions on What Matters Most, San Francisco, CA: Jossey-Bass.

Foner, E. (1970 [1995]), Free Soil, Free Labor, Free Men: The Ideology of the Republican Party Before the Civil War, With a New Introductory Essay, Oxford: Oxford University Press.

Frank, T. (2004), What's the Matter with Kansas: How Conservatives Won the Heart of America, New York: Henry Holt.

Geiger, R.L. and N.M. Sorber (eds) (2013), The Land-Grant Colleges and the Reshaping of American Higher Education, New Brunswick, NJ: Transaction.

Habermas, J. (1973 [1975]), Legitimation Crisis, Boston: Beacon Press.

Habermas, J. (1986), 'The New Obscurity: The Crisis of the Welfare State and the Exhaustion of Utopian Energies,' Philosophy and Social Criticism, 11(2), 1-18. 
Harvard Faculty Committee (1945), General Education in a Free Society, with an Introduction by James Bryant Conant, Cambridge, MA: Harvard University Press.

Harvey, D. (1989), The Condition of Postmodernity: An Enquiry into the Origins of Cultural Change, New York: Wiley-Blackwell.

Henderson, S. (2016), 'Betsy DeVos and the Twilight of Public Education,' Detroit Free Press, December 3, available at: http://www.freep.com/story/opinion/columnists/stephen-henderson/ 2016/12/03/betsy-devos-education-donald-trump/94728574/.

Hossler, D. and B. Bontrager (2014), Handbook of Strategic Enrollment Management, San Francisco, CA: Jossey-Bass.

Hrabowski, F.A., III (2016), 'Foreword,' in P. Felten, J.N. Gardner, C.C. Schoreder, L.M. Lambert, and B.O. Barefoot, The Undergraduate Experience: Focusing Institutions on What Matters Most, San Francisco, CA: Jossey-Bass, pp. vii-xii.

Jaschik, S. (2016), 'Giving the Finger to K-State and General Education,' Inside Higher Education, December 21, available at: https://www.insidehighered.com/news/2016/12/21/freshmanannounces-hes-dropping-out-kansas-state-and-sets-debate-general-education.

Judis, J.B. (2014), 'This is What's the Matter with Kansas,' New Republic, September 29, available at: https://newrepublic.com/article/119574/sam-brownbacks-conservative-utopia-kansas-hasbecome-hell.

Katznelson, I. (2013), Fear Itself: The New Deal and the Origins of our Time, New York: Liveright Publishing.

Leonhardt, D. (2017), 'America's Great Working-Class Colleges,' The New York Times, January 18, available at: https://www.nytimes.com/2017/01/18/opinion/sunday/americas-great-workingclass-colleges.html?rref=collection $\% 2$ Fcolumn $\% 2$ Fdavid-leonhardt\&action=click\&content Collection $=$ opinion $\&$ region $=$ stream $\&$ module $=$ stream_unit\&version=latest\&contentPlace ment $=40$ \&pgtype $=$ collection .

Levitz, E. (2016), 'The Republican Party Must Answer for What it Did to Kansas and Louisiana,' New York magazine, March 18, available at: http://nymag.com/daily/intelligencer/2016/03/ gop-must-answer-for-what-it-did-to-kansas.html.

MacIntyre, A. (1981), After Virtue: A Study in Moral Theory, Notre Dame, IN: University of Notre Dame Press.

McGee, J. (2015), Breakpoint: The Changing Marketplace for Higher Education, Baltimore, MD: Johns Hopkins University Press.

Menand, L. (2001), The Metaphysical Club: A Story of Ideas in America, New York: Farrar, Straus, and Giroux.

Menand, L. (2010), The Marketplace of Ideas: Reform and Resistance in the American University, New York: W.W. Norton.

Mills, C.W. (1951), White Collar, Oxford: Oxford University Press.

Mills, C.W. (1956), The Power Elite, Oxford: Oxford University Press.

Mills, C.W. (1959), The Sociological Imagination, Oxford: Oxford University Press.

Mortenson, T.G. (2012), 'State Funding: A Race to the Bottom,' The Presidency, Winter, American Council on Education, available at: http://www.acenet.edu/the-presidency/columnsand-features/Pages/state-funding-a-race-to-the-bottom.aspx.

Nevins, A. (1962), The State Universities and Democracy, Ames, IA: Iowa State University Press.

O'Connor, J. (1973), The Fiscal Crisis of the State, New York: St. Martin's Press.

Offe, C. (1984), Contradictions of the Welfare State, Cambridge, MA: MIT Press.

Offe, C. (1985), Disorganized Capitalism: Contemporary Transformations of Work and Politics, Cambridge, MA: MIT Press.

Padilla, A. (2005), Portraits in Leadership: Six Extraordinary University Presidents, Westport, $\mathrm{CN}$ : American Council on Education/Praeger Series on Higher Education.

Peters, S.J. (2013), 'Storying and Restorying the Land-Grant System,' in R.L. Geiger and N.M. Sorber (eds), The Land-Grant Colleges and the Reshaping of American Higher Education, New Brunswick, NJ: Transaction, pp. 335-353.

Piketty, T. (2014), Capital in the Twenty-First Century, Cambridge, MA: The Belknap Press of Harvard University Press. 
Quiring, V.M. (ed.) (1986), The Milton S. Eisenhower Years at Kansas State University, Manhattan, KS: Friends of the Libraries at Kansas State University.

Reeves, R. (2015), Infamy: The Shocking Story of the Japanese American Internment in World War II, New York: Henry Holt.

Ross, A. (2016), 'The Frankfurt School Knew Trump was Coming,' December 5, The New Yorker, available at: http://www.newyorker.com/culture/cultural-comment/the-frankfurtschool-knew-trump-was-coming.

Ross, E.D. (1942), Democracy's College: The Land-Grant Movement in the Formative Stage, Ames, IA: Iowa State University Press.

Selingo, J.J. (2013), College (Un)Bound: The Future of Higher Education and What it Means for Students, Seattle, WA: New Harvest.

Smith, R.G. (2013), The People's Colleges: A History of the New York State Extension Service in Cornell University and the State, 1876-1948, Cornell, NY: Cornell University Press.

Steiner, P. (2003), 'Physiocracy and French Pre-classical Political Economy,' in W.J. Samuels, J.E. Biddle, and J.B. Davis (eds), A Companion to the History of Economic Thought, Malden, MA: Blackwell, pp. 61-77.

Sternberg, R.J. (ed.) (2014), The Modern Land-Grant University, West Lafayette, IN: Purdue University Press.

Stewart, K. (2016), 'Betsy DeVos and God's Plan for Schools,' op-ed., The New York Times, December 13, available at: http://www.nytimes.com/2016/12/13/opinion/betsy-devos-andgods-plan-for-schools.html.

Suellentrop, C. (2015), 'The Kansas Experiment,' The New York Times Magazine, August 9, available at: http://www.nytimes.com/2015/08/09/magazine/the-kansas-experiment.html.

Taub, A. (2016), 'The Rise of American Authoritarianism,' VOX, March 1, available at: http:// www.vox.com/2016/3/1/11127424/trump-authoritarianism.

Thackrey, R.I. (1986), 'The "Eisenhower Era” at Kansas State University,' in V.M. Quiring (ed.), The Milton S. Eisenhower Years at Kansas State University, Manhattan, KS: The Friends of the Libraries of Kansas State University, pp. 31-61.

Tuchman, G. (2009), Wannabe U: Inside the Corporate University, Chicago: University of Chicago Press.

Walker, R.A. (1986), 'The Milton Eisenhower I Knew,' in V.M. Quiring (ed.), The Milton S. Eisenhower Years at Kansas State University, Manhattan, KS: The Friends of the Libraries at Kansas State University, pp. 62-82.

Weissmann, J. (2016), 'Why Conservatives Have Learned Nothing from Kansas' Disastrous Tax Cuts,' Slate, available at: http://www.slate.com/blogs/moneybox/2016/04/20/kansas_tax_ cuts_are_a_mistake_and_everyone_agrees.html.

Wolfe, A. (1977), The Limits of Legitimacy: Political Contradictions of Contemporary Capitalism, New York: Free Press.

Yamamoto, E.K., M. Chon, C.L. Izumi, J. Kang, and F.H. Wu (2013), Race, Rights, and Reparation: Law and the Japanese American Internment, 2nd edn, New York, NY: Aspen Publishers.

Zernike, K. (2016), 'Betsy DeVos, Trump's Education Pick, Has Steered Money from Public Schools,' The New York Times, November 23, available at: http://www.nytimes.com/2016/ 11/23/us/politics/betsy-devos-trumps-education-pick-has-steered-money-from-publicschools.html. 